\title{
The Structural Differences in Consumption Taxes and Their Financial Fractional Distribution Effects in OECD Countries
}

\author{
A. Niyazi Özker \\ Public Finance Department, Faculty of Economic and Business Administration, Bandirma Onyedi Eylul University - 10200, Turkey
}

Copyright $(2018$ by authors, all rights reserved. Authors agree that this article remains permanently open access under the terms of the Creative Commons Attribution License 4.0 International License

\begin{abstract}
In this study, we aim to put forth the effective levels of the consumption taxes both different application structures and disintegration effects as subjected different applications in OECD countries. As is known to all the consuming taxes seem difference in both situations as the taxes applications and structural financial formation according to the related countries, which mean also to the varieties of financial institutionally dynamics in term with regard to the developed levels of these countries based. In this context, the financial fractionally effects can be accepted as the important fact, especially in OECD countries, because the consumption taxes towards households' purchasing powers are affected by the rates of consuming taxes in the process of increasing indirectly. In addition, the differences in each other of consumption taxes in OECD contribute on GDP, especially based on the value added, are connected with the countries' different developed levels, and this fact ensure to deal over the financial confused towards economic integration unities. However, the structural difference of consumption taxes in practices that are especially in the international area put forth not positive financial effects sometimes due to cause the financial disintegrate in order to ensure the financial units. It appears that it should be formatted balances between the national tax practices and the global tax practices to positive distribution of the tax burden. In this context, the main problem with the consumption taxes approach is how to interpret the results obtained according to evaluating distributional impact of consumption taxes across households.
\end{abstract}

Keywords Consumer Surplus, Consumption Taxes, Financial Effects, OECD, Value Added

JEL Codes: G18; O11; O12; O19.

\section{Introduction}

The consumption taxes have some different features with financial effects criteria on the households' purchasing powers, which are affected by financial confused disintegrations especially in the financial process. The consumption tax revenues collected in OECD countries have continued increasing from last year's all-time high increasing share of total tax revenues according to OECD current researches. Under this situation, the consumption tax alterations on the household attitudes should be known. The financial disintegration effects of the consume taxes are able to cause the deflections to the common applicability because households' consumption should not respond to these changes in tax rates since they are expected. As related to this matter, Hall and Mishkin (1982) [6] studied on the disintegration effects of the consume taxes, considering that the consumption effects and responds strongly to permanent in order to transitory movements of household income. Later, Leibfritz, Thornton and Bibbee (1997) [13] investigated on the disintegration effects of the local consume taxes in the economic developing process. Certainly, one of the most valid studies is, as tax policy study, OECD's study [21] including the confused-distributional effects of the consume taxes that also is valid nowadays. What more important is the changing levels of consuming taxes according to the previous years to put forth the structural different in the consumer expenditure process. In this concept, the academic approach study on the effect of taxes changes on consuming taxes, it needs attention to consider the structural alteration affects, which are important especially after 2009 financial crisis [24]. In addition, applying this theory to the changes of consuming taxes as related to the structural different is possible to conclude that consumers will be more likely to alter their spending pattern if they perceive a tax change to be lasting after financial crises. In 
this point, it should be targeted that a reduction in income tax rates to increase the levels of consuming or increase in personal exemptions is placed permanently, which should have a larger effect on consumer toward to ensure the structural alteration of consuming taxes. Of course, it should be accorded that the consuming theory cannot be possible to predict accurately different consuming patterns every time related to spending associated with a change in the permanent consuming taxes. In this situation, it can be expected that the consumers spending will not change until a tax changes, or consumers are affected directly by the size of a consuming tax changes that express its effect on tax liabilities but only in a short time. The structural difference related to the consuming taxes can put forth some other socio-economic political approaches and this concept means the variations are between monetary supplies and interest rates. Consumers do not perfectly smooth their demands for goods at quarterly frequencies across expected income changes as the related consumption taxes. Although the developing volume of market dynamics is the reason of this structural fact, the developing countries in OECD choose the contractionary financial and monetary policies to catch sustainability process. In this stage, it is possibly seen that consumers' smooth expenditures across predictable income fluctuations to be related to liquidity is constrained in order to increasing their desired savings in developing countries. [18]. In this context, the confused distributional effects of consumption tax occur especially as related to the macroeconomics balances including income redistribution, and this fact means consumption reacts in an economically significant manner to predictable changes in tax rates. On the other hand, the elasticity of expenditures on consuming goods with respect to the predictable declines in income is also regarded meaningful to analyze distributional effects of consumption taxes in the same period.

\section{The Distributions of Some Main Taxes and the Locations of Consumption Taxes in OECD}

As the other indirect taxes, the consumption taxes are quite important for all countries and, of course, it is a significant public revenue source. Generally, the consumption taxes limits have more limits in less developed or developing countries than the developed countries, which means there is no equitable tax alteration for less developed countries. Therefore, it is seen that contrary to the basic consumption reacts in an economically significant manner to predictable changes in the consumption tax rates especially developing countries in OECD. For example, direct tax from earning amount is approximately $61.2 \%$ in total tax revenues as percent in OECD, whereas the income from consumption taxes is around 18.9 percent. As a member of OECD like Turkey, in some countries, consumption taxes amount number have $58 \%$ in the total tax revenues. Table 1 below expresses the main taxes and the locations of consumption taxes in OECD for 2016.

Table 1. Comparison of OECD Countries in Total Tax (Approximately)

\begin{tabular}{|c|c|c|c|c|c|c|c|c|c|c|c|}
\hline & USA & $\begin{array}{c}\text { Canad } \\
\mathbf{a} \\
\end{array}$ & $\begin{array}{c}\text { Mexic } \\
0 \\
\end{array}$ & UK & $\begin{array}{c}\text { German } \\
y\end{array}$ & France & $\begin{array}{c}\text { Finlan } \\
\mathrm{d}\end{array}$ & $\begin{array}{c}\text { EU } \\
\text { (unweig } \\
\text { hted) } \\
\end{array}$ & $\begin{array}{c}\text { Austral } \\
\text { ia }\end{array}$ & \begin{tabular}{|c|} 
Japan \\
(some taxes \\
missing) \\
\end{tabular} & $\begin{array}{l}\text { OECD } \\
\text { (unwei } \\
\text { ghted) }\end{array}$ \\
\hline $\begin{array}{l}\text { Personal } \\
\text { Income Tax }\end{array}$ & 35.3 & 34.6 & NA & 28.7 & 23.9 & 17.5 & 31 & 25 & 38.5 & 17.5 & 24.9 \\
\hline Corporation Tax & 8.1 & 10.4 & NA & 7.8 & 3.5 & 5.7 & 7.7 & 8.1 & 16.7 & 13 & 9.3 \\
\hline $\begin{array}{l}\text { Social Security } \\
\text { Contribution }\end{array}$ & 26.4 & 17.5 & 18.7 & 18.5 & 40.5 & 40.2 & 26.7 & 29.8 & 5.6 & 18.5 & 27 \\
\hline $\begin{array}{l}\text { Direct Tax from } \\
\text { earning }\end{array}$ & 69.8 & 62.5 & 18.7 & 55 & 67.9 & 63.4 & 65.4 & 62.9 & 60.8 & 49 & 61.2 \\
\hline Property Tax & 12.1 & 10 & 1.6 & 11.9 & 2.4 & 7.3 & 2.3 & 5.4 & 9.5 & 10.3 & 5.6 \\
\hline $\begin{array}{l}\text { Goods and } \\
\text { Service Tax }\end{array}$ & 18.2 & 26.1 & 52.5 & 32.7 & 29.4 & 25.5 & 32 & 30.4 & 29.7 & 20.3 & 32.1 \\
\hline $\begin{array}{l}\text { Consumption } \\
\operatorname{Tax}(\text { in GST) }\end{array}$ & 8.4 & 15.1 & 19.4 & 19.8 & 17.9 & 16.8 & 19.4 & 18.9 & 13.7 & 9.5 & 18.9 \\
\hline
\end{tabular}

Source: Brys, Bert; Matthews, Stephan and Owens, Jefreyy (2011), Tax Reform Trends in OECD Countries, OECD Taxation Working Papers, No. 1, Paris: OECD Publishing, 2011, p. 10-13. 
As seen table 1, consumption taxes have a wavy situation level in OECD countries for 2016, but the striking feature here is that the share of consumption tax in the USA has fallen to 8.4 per cent of the share of total tax revenues. This phenomenon can be explained by the fact that the present level of direct taxes is at a relatively high level of about 70 percent of the total tax revenues. Personal and corporation taxes are over 30 percent as total each other, which means direct taxes place an important value in the total taxes amount together with social security taxes in the same process [1]. The consumption taxes have important dynamics that steer the process in spite of their take places less in the total taxes amount especially as considered for determining buying power, and this situation is never ignored. Certainly, these consumption taxes processes also carry key dynamos related to the alteration dynamics as their taxes incidences with respect to pre-tax and post-tax situation. If we want to consider tax revenues including consumption taxes from a different perspective as of 2017, the consumption taxes could be seen as a percent of GDP for OECD. Table 2below puts forth this financial situation for OECD.

Table 2. Taxes Ratios including Consumption Taxes in OECD, 2017 (as $\%$ of GDP)

\begin{tabular}{|l|c|r|r|r|} 
Country & $\begin{array}{c}\text { Income } \\
\text { Taxes }\end{array}$ & $\begin{array}{l}\text { Payroll } \\
\text { taxes }\end{array}$ & $\begin{array}{l}\text { Consumption } \\
\text { Taxes }\end{array}$ & $\begin{array}{l}\text { Total } \\
\text { Taxes }\end{array}$ \\
\hline Australia & 18.4 & - & 8.2 & 30.8 \\
\hline Canada & 16.6 & 4.8 & 7.9 & 33.3 \\
\hline United Kingdom & 14.3 & 6.6 & 10.5 & 36.1 \\
\hline United States & 13.9 & 6.6 & 4.7 & 28.3 \\
\hline OECD Total & 13.2 & 9.1 & 10.9 & 35.8
\end{tabular}

Source: OECD, Revenue Statics 2017 - Tax Revenue Trends in OECD, 2017.

This financial formation effects on the structural alteration process related to consumption taxes especially in supply elasticity to increase the marginal productivity in the same process. On the other hand, this formation brings up the precautionary saving or a constraint on borrowing is causing the failure of consumption smoothing. But, this productive approach is not seen possible, as a member of OECD, in some developing countries because of the composition of taxes on goods and services that has fundamentally changed in during this period. Unfortunately, on other hand this phenomenon has increased the negative effect of consumption taxes as marginal distribution values especially causing worse in modern OECD countries [4]. In addition, this financial fractional structure means that against pure consumption smoothing has potentially far-reaching implications in OECD countries.

\section{The Structural Alteration Process Dynamics of Consumption Taxes}

The alteration process of consumption taxes related to their own dynamics can be expressed in two terms: First, the consumption taxes affect capital formation, especially on value added taxes that are allocated to capital owners by the reduction in taxes due to expensing. On the other hand, this process results in the more stability process according to consumption taxes toward to more national increasing capital. This fact put forth on by the reduction in taxes due to expensing means more gains for public institutions because of the increasing public expenditures' multiplier effects on GDP. This phenomenon is needed especially in the developing countries in OECD to catch the desired economic growth levels for a while [14]. Moreover, this fiscal formation support is a main dynamic that ensure a consumption tax is a balanced combination of a wage tax plus this lump sum tax in economic and monetary policies. Second, the next notion in terms is related to the consumption taxes burden on both the consumer and capital formation. Briefly, the burden of a consumption tax are those who own capital before a consumption tax is implemented, but the alteration dynamics (ignoring transitional dynamically rules) create important their own tax reform dynamics in the related process. This phenomenon gives alterations dynamics to the distinction between "old consumption taxes" and "new consumption taxes applications" as an important issue in tax reforms. For developing countries, the transitional alteration of consumption taxes difficulties has stood as a major obstacle to wholesale change especially in developing countries for OECD. However, tax alterations dynamics for consumption taxes has been piecemeal changed toward to balance an income tax and consumption tax system. Generally, the substitutional effects of old consume dynamics have been the financial problems that aim to get over gradually on consumption on the tax burden [25]. Therefore, the alteration of consumption taxes dynamics has been based from a predominant reliance on income, as the tax base toward a greater reliance for consumption taxes. This is the second main problematic that needs to be overcome for the consumption the process. In addition, it can be possible to mention the three dynamics of variation which identify the effect of the changing tax rates on consumption in itself related to the consumption taxes applications. First, the marginal consumption rates lose meaning in the related process due to high-income individuals hit the optimal social tax limits in the consumption taxes process, which is also related to household income rates [19]. Second, all the tax income rises, in different period, that depend on each individual's income affect marginal consumption rates, in spite of there is not the change rate of the consumption taxes, and then this fiscal fact occurs the negative effect on the redistribution income for individuals [7]. Thus, there can be a large percentage negative reduction in the modification of consumption of households, but it means completely regular consumption across consumption tax changes due to the optimal national income distribution [7]. 


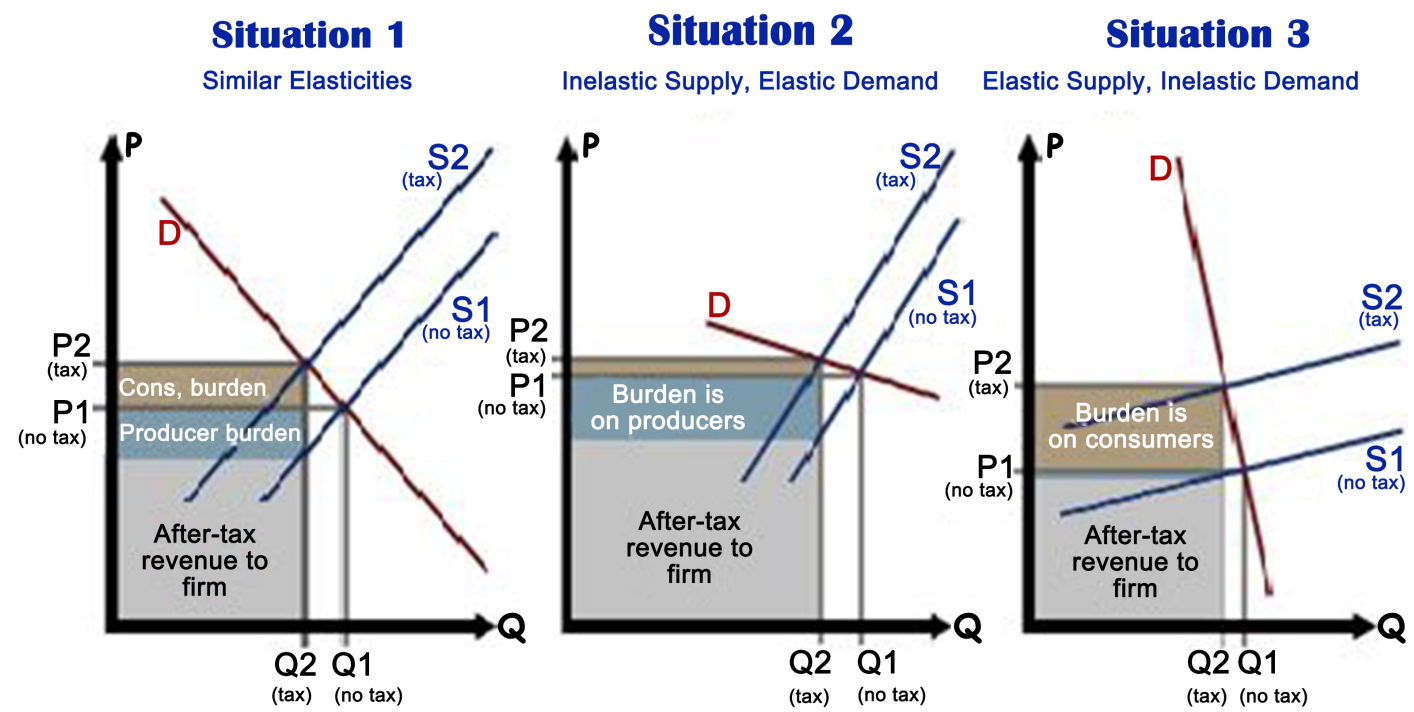

Source: IRET (2004), “Tax Incidence, Tax Burden, and Tax Shifting: Who Really Pays The Tax”, Policy Bulletin, September 10, No. 88, 2004.

Figure 1. Consumption Tax Incidence

Therefore, the consumption taxes incidences can be dealt with in three term situation related to their structural alteration process dynamics especially in OECD countries. First, the taxation elasticities related to tax burden comparison with after tax period and before tax period. Second, in the after consumption tax, the structural alteration in the framework of inelastic supplied with the elastic demand needs the incentives for supply units [1]. Third, the structural phenomenon dynamics related to the alteration process in the alteration position of the elastic supply together within inelastic demand, and that situation means the decrease of consumption taxes burdens for consumers [1]. Figure 1 below expresses all these related processes that are in the scope of consumption taxes alteration process.

The related figure in the situation (1) expresses the alteration incidence of consumption tax in both elasticities and the demand and supply that effect on price with quantity. In this situation, as prices and quantity are of process dynamics, put forth elasticity that effect on production supply, and this means financial income problems can be get over more easily for public budget needed [16]. Moreover, this situation makes it possible to mention in the positive reciprocal influence the effect of the changing tax rates on consumption in itself related to the consumption taxes applications [12]. Therefore, in personal income redistribution, the key dynamics that determines consumption taxes limits can make change toward to balance an income tax and consumption tax system in the long-run and solve particular cases of the household's optimization problem [17].

But this approach has been not to occur in OECD countries due to the alteration process consumption have been not determined related to the different consumption taxes rates. As the situation (2) and (3) only express the theoretical framework, this formation is not taken into account throughout OECD countries to analyze the financial distributional effects and it is not seem possible in the alteration process for these countries [17]. In brief, it can be said that consistent with some stories of bounded rationality, the strongest violations of consumption smoothing occurs in subcategories of consumption in which households can easily substitute purchases across time. The effects of a consumption tax are somewhat more different from those of a production tax or income tax in OECD countries. Namely, a consumption tax tends to encourage savings, investment and discourage consumption in especially developing countries in OECD as related to the desired flexible demand and supplying curves in the structural alteration process. Therefore, those developing countries can put forth this argument for a national consumption tax in OECD countries point to it as a revenue source that could be used to reduce the national deficit and improve the nation's trade balance [12].

\section{The Marginal Productivity Approach of Consumption Taxes in Their Financial Distributional Effects}

The marginal productivity approach that can be evaluated of the consumption taxes in two terms generally for OECD countries can also mean the elastically criteria according to demand and supply, which mean to determine the structural different of these. First, the formation fact related to purchase power is consumer surplus occurred after tariff, and in this situation, the supply limits have less elastically then demand [22]. In this situation, the generally price levels that are related to domestic goods' prices will be higher than the price before tariff, and the distributional 
effect of these consumption taxes is negative [5]. This phenomenon can cause more import levels due to the domestic interest rates increase in the same period, which means to go down in the prices of the import goods and their cheaper than before. In recent times, this has been the opposite in the OECD countries related to the distributional financial effects because especially in developing countries like Turkey, the national domestic currency has been to live on the devaluation due to the extent variable financial conditions [9]. Figure 2 below expresses this concerned situation after tariff of the consumption taxes:

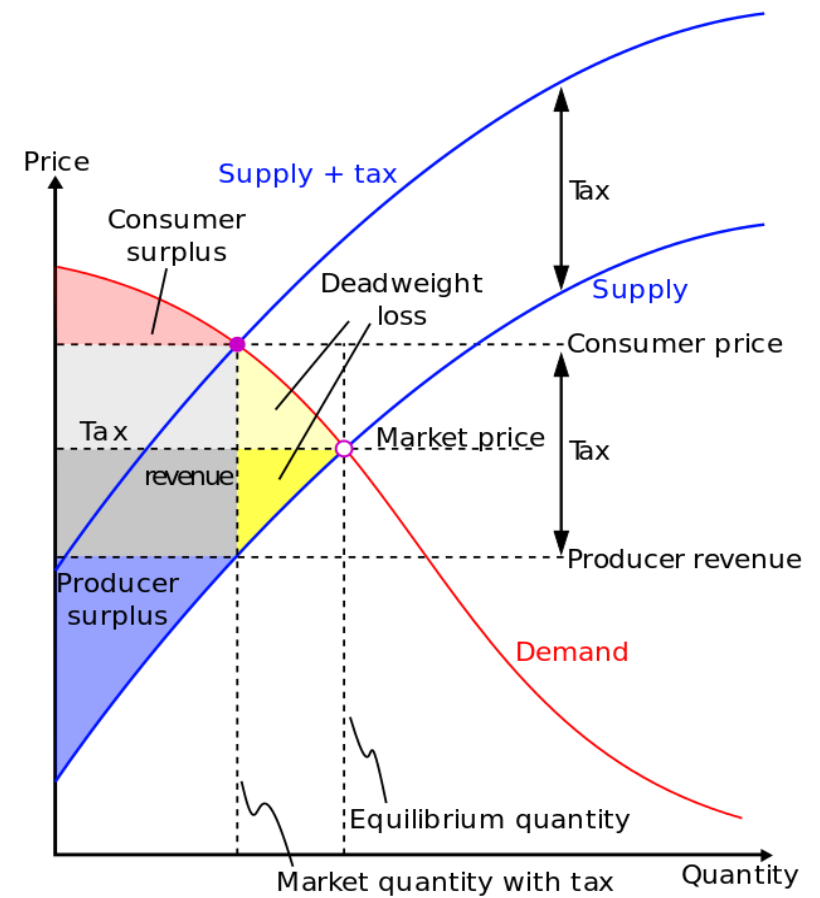

Sources: OECD (2004), An Analysis of Diary Policy Reform and Trade Liberalization Trade and Economic Effect of Milk Quoto Systems, COM/AGR/TD/WP(2004)19/FINAL, OECD 2004.

Figure 2. The Marginal Productivity Deviation and Distributional Effects of The Consumption Taxes Occurred

Figure 2 expresses equilibrium quantity with demand and supply elastically for developing countries in OECD. As seen on the figure 2, the consumer's surplus is less in developing countries than the developed countries' surplus levels. This structural location has been to cause also typically have a production limiting in especially the developing countries in OECD. Namely, it can be said that where the reduction of total supply can be considered over a period of time progressively of regressively, and really also it has been occurred, as said, for currently days. This situation puts forth the elasticity of expenditures on non-durable goods with respect to the predictable declines in income in OECD countries. From this perspective, the marginal productivity and distributional effects occurred that are related to of the consumption taxes in OECD should be considered within the consumer surplus and market prices' equilibrium points [20]. And also, the other equilibrium points producer surplus is often an important dynamic that should be balanced with consumer surplus since a long time, and this phenomenon could not be getting over in order to catch the desired developing levels due to the developing countries' increasing import levels [8]. In brief, the efficient producers desire to tax regulation the consumption taxes in a competitive provided that a rate equal to the difference between support price and marginal cost to arrive the desired producers' surplus [11]. The analysis presented in figure 2 puts forth that the deadweight loss, as welfare value, are more due to the consumption taxes rates extremely increased. In this respect, marginal productivity and positive prosperity distribution in the OECD countries have been more negative influenced than in the past related to the consumption taxes. For this reason, it is seen that all the structural change dynamics related to consumption taxes are required primarily based on the developing countries to financial fractionally distributional effects [2]. That is the fractional effects expected of consumption tax have been led to significant different distribution effects between developed and developing countries, and this current formation means that within the OECD countries undoubtedly the differentiation of the purposes for which the consumption tax is to be used. This long-run effect brings into question the durability of the above-described these taxes efficiency of policies involving fractionally constraints.

\section{Conclusions}

Consumption taxes constitute a significant difference in the distributional effects among OECD countries, indicating that they have different periodic effects on different functional approaches. Both the demand elasticity and the supply elasticity are the meaningful reasons for the most significant level of impact on the different consumer surplus, and the consumption taxes have an important impact on the production levels within the production efficiency. On the other hand, it is also understood that creates significant deviations from the targeted point via these concerned consumption taxes especially in developing countries in OECD. In reality, the net gain to public budgets is conditional on the share of surplus split between producer surplus factors of production and the size of the consumption that are affected by the consumption taxes limits. This position can be considered, as an OECD member has led developing countries to more applications used in the scope of indirect taxes. This structural change and difference means that the financial fractional structure is further deteriorating.

This location related to the structural different also has caused the conclusion that has put up with often even more unsuccessful especially in developing countries that are in the scope of OECD. However, it can be expected that the assumption that the surplus of production should equal with the tax on production would be optimal to apply a 
consumption tax, which balances the excess of the consumer. However, the consumption tax limits on consumer surplus are quite large in developing countries, and it appears that this is the most important reason for the increasing negative fractional effect in spite of the total consumption tax amount is less. In this sense, it is not possible to mention the distribution of a meaningful consumption tax within the OECD countries due to there being more the developing countries than the developed countries as members of OECD. The welfare deviation created by consumption taxes is also evident in the fact that developing countries have a significant increase in tax burden and divergence. These countries' currency values have lower global values convertibility than the international values appreciated in the international monetary markets. Therefore, in respect of public deficits, one reason for the ever-increasing consumption taxes in these developing countries is that consumption taxes as a public income are seen as a lifesaver for this reason.

\section{REFERENCES}

[1] Apps, P. and Rees, R. (2003), "Fertility, Taxation and Family Policy",http://www.versicherung.vwl.lmu.de/perso nen/rees/Fertsje0204.pdf, (28.1.03.2017).

[2] Baillie, R. T. (1996), "Long Memory Processes and Fractional Integration in Econometrics", Journal of Econometrics, 73, 1996, pp. 5-59.

[3] Brys, Bert; Matthews, Stephan and Owens, Jefreyy (2011), Tax Reform Trends in OECD Countries, OECD Taxation Working Papers, No. 1, Paris: OECD Publishing, 2011.

[4] Charlet, A. and Owens, J. (2010), “An International Perspective on VAT", Tax Notes International, 50(12), September 2010, pp. 943-954.

[5] Đorđević, M. and Perović, D. (2016), "An Analysis of Consumption Taxes Regressive Effects", TEME, г. XL, бр. 4, pp. 1399-1420.

[6] Hall, R. E. and Mishkin, F. S. (1982), "The Sensitivity of Consumption to Transitory Income: Estimates from Panel Data on Households", Econometrica, 50(2), (March 1982), pp. 461-481.

[7] Gale, W. G. and Samwick, A. A. (2014), Effects of Income Tax Changes on Economic Growth, The Brookings Institution, 2014.

[8] Ghose, A. and Han, S. P. (2014), "Estimating Demand for Mobile Applications in the New Economy", Management Science, 60(6), 2014, pp. 1470-1488.

[9] Gürel, S. P. and Lenger, A. (2016), "The Nonlinear Analysis of External Dynamics on Economic Growth: The Case of Turkey", International Journal of Business and Economic Sciences Applied Research, 9(1), 2016, pp. 57-68.

[10] IRET (2004), “Tax Incidence, Tax Burden, and Tax
Shifting: Who Really Pays the Tax", Policy Bulletin, September 10, No. 88, 2004, pp. 1-52.

[11] Lam, C. T. and Liu, M. (2017), Demand and Consumer Surplus in the On-demand Economy: The Case of Ride Sharing, October 11, 2017, http://ide.mit.edu/sites/default/f iles/publications/SSRN-id2997190.pdf (28.03.2018).

[12] Lehmus, M. (2010), Labour or Consumption Taxes? An application with a Dynamic General Equilibrium Model with Heterogeneous Agents, Labour Institute for Economic Research- Discussion Papers 264, Helsinki: Labour Institute for Economic Research 2010.

[13] Leibfritz, W.; Thornton, J. and Bibbee, A. (1997), Taxation and Economic Performance, Economic Department Working Papers No: 176, OCDE/GD (97)107.

[14] Macinko, J.; Starfield, B. and Shi, L. (2003), "The Contribution of Primary Care Systems to Health Outcomes within Organization for Economic Cooperation and Development (OECD) Countries, 1970-1998", Health Services Research, 38(3), Jun, 2003, pp. 831-865.

[15] OECD (2004), An Analysis of Diary Policy Reform and Trade Liberalization Trade and Economic Effect of Milk Quoto Systems, COM/AGR/TD/WP(2004)19/FINAL, OECD 2004.

[16] OECD (2005), Recommendation on Principles and Good Practices for Financial Education and Awareness, OECD Directorate for Financial and Enterprise Affairs, 2005.

[17] OECD (2010), OECD Economic Surveys United States, Volume 2010/15, September 2010.

[18] OECD (2011), Tax Reform Trends in OECD Countries, OECD $50^{\text {th }}$ Anniversary Challenges in Designing Competitive Tax Systems, Paris, 30 June 2011.

[19] OECD (2012), "Reducing Income Inequality While Boosting Economic Growth: Can It Be Done?", Economic Policy Reforms 2012 Going for Growth, OECD 2012, pp. 181-202.

[20] OECD (2013), The OECD Handbook for Fisheries Managers-Principles and Practice for Policy Design, October 8, 2013, OECD Publishing 2013.

[21] OECD (2014), The Distributional Effects Consumption Taxes in OECD Countries, OECD Tax Policies Studies No: 22, OECD and Korea Institute of Public Finance No: 22, 2014.

[22] OECD (2016), OECD-FAO Agricultural Outlook 2016-2025 - Special focus: Sub-Saharan African, OECD/Food and Agriculture Organization of The United Nations, OECD Publishing, Paris 2016.

[23] OECD (2017), Revenue Statics 2017 - Tax Revenue Trends in OECD, 2017.

[24] Steindel, C. (2001), "The Effect of Tax Changes on Consumer Spending", Current Issues in Economic and Finance, 7(11), December 2001, pp. 1-6.

[25] Winner, H. (2005), "Has Tax Competition Emerged in OECD Countries? Evidence from Panel Data", International Tax and Public Finance, 12(5), September 2005, pp 667-687. 